\title{
INTEGRASI TEOLOGI DAN PSIKOLOGI DALAM PELAYANAN PASTORAL KONSELING KRISTEN
}

\author{
Sherly Mudak
}

\section{PENDAHULUAN}

Dalam sejarah integrasi teologi dan psikologi, beberapa teolog Kristen menolak upaya ini. Alasan penolakan mereka antara lain: pertama, ada yang menganggap bahwa sistem nilai Kristen dan non-Kristen berbeda. Kedua, ilmu psikologi dianggap sebagai ilmu pengetahuan, sedangkan ilmu teologi dianggap sebagai filosofi sistem keagamaan. Jadi, dua bidang yang sangat berbeda ini tidak mungkin diintegrasikan. Anggapan yang lebih radikal adalah psikologi ditemukan oleh orang-orang non-Kristen bahkan anti-Tuhan, oleh karena itu, menurut psikologi tidak layak diintegrasikan dengan teologi. Asumsi lainnya adalah psikologi didasarkan pada pikiran manusia dan bertentangan dengan Alkitab. Jadi, orang Kristen cukup menyelesaikan masalah emosinya dengan berdoa dan baca Alkitab saja. Topik Integrasi Teologi dan Psikologi, mempresentasikan bagaimana membawa kebenaran Allah, dari segala bidang yang diciptakan-Nya, untuk menunjang karya-Nya atas umat manusia yang dikasihi-Nya.

\section{PENGERTIAN ISTILAH}

Sebelum membahas lebih jauh, maka penulis terlebih dahulu akan menjelaskan apa yang dimaksud dengan integrasi teologi dan psikologi. Integrasi, pada Kamus Besar Bahasa Indonesia bermakna pengertian pembauran hingga menjadi kesatuan yang utuh atau bulat. ${ }^{1}$ James Widodo mendefinisikan integrasi sebagai suatu sinergi antara beberapa disiplin ilmu yang berlainan tanpa menghilangkan ciri ilmu masing-masing. Beberapa disiplin ilmu yang berlainan tersebut bersifat saling melengkapi untuk memberikan world view yang lebih luas sehingga dapat memberikan pemahaman yang lebih utuh dalam melihat suatu fenomena. ${ }^{2} \mathrm{Jadi}$, dalam

1 Departemen Pendidikan \& Kebudayaan, Kamus Besar Bahasa Indonesia (Jakarta: Balai Pustaka, 1989), 335

2 James Widodo, Konseling Dalam Pelayanan Geraja Masa Kini, http://www.mail.archive.com/, (diakses, 25 Spetember 2007) 
konteks konseling, integrasi diartikan sebagai pembauran antara theologia dan psikologi hingga menjadi satu kesatuan yang utuh atau bulat tanpa menghilangkan ciri ilmu masing-masing.

Theologia, dari kata Yunani, yaitu theos yang berarti "Tuhan", dan logos, berarti "kata, wejangan, ajaran." 3 Webster mengartikan kata theology sebagai, "Studi tentang doktrin-doktrin agama dan hal-hal keilahian: lebih spesifik, studi tentang Tuhan dan hubungan antara Tuhan, umat manusia, dan alam semesta." Sedangkan menurut Lorens Bagus, Theologia berarti "ilmu tentang hubungan dunia ilahi (atau ideal, atau kekal tak berubah) dengan dunia fisik." Jadi, istilah theologia artinya suatu pernyataan atau interpretasi kebenaran tentang Allah dan ciptaan-Nya.

Psikologi, berasal dari kata psyche yang berarti pikiran dan logos yang memiliki arti ilmu yaitu ilmu yang mempelajari tingkah laku manusia yang dapat diamati (observerable). ${ }^{5}$ Istilah perilaku atau tingkah laku digunakan dalam arti luas untuk memasukkan segala sesuatu yang manusia atau hewan bisa melakukannya. ${ }^{6}$ Tingkah laku ini kadangkala sifatnya terbuka atau umum, kadangkala tersembunyi, samar-samar. ${ }^{7}$ Dari pengertian tersebut maka dapat disimpulkan bahwa Psikologi merupakan sebuah bidang ilmu yang mempelajari dan mengamati tingkah laku manusia yang terbuka maupun tersembunyi.

Usaha untuk mengintegrasikan theologia Kristen dengan ilmu psikologi banyak mendapat kecaman atau tantangan. Orang Kristen telah bereaksi dalam berbagai cara untuk munculnya psikologi modern, namun beberapa telah menyambut dengan tangan terentang. Bagi mereka, wawasan psikologi adalah sekutu besar untuk Gereja karena membawa misinya di dunia. Lainnya menolak psikologi karena mereka melihat di dalamnya ancaman implisit untuk Gereja dan otoritas Alkitab. ${ }^{8}$ Hal ini mengindikasikan bahwa ada pihak yang menerima integrasi theologia dan psikologi dengan tangan terbuka, namun ada juga yang tidak menerima

${ }^{3}$ Henry C. Thiesen, Teologi Sistematika (Malang: Gandum Mas, 2000), 2

${ }^{4}$ Agnes (Ed), Webster's New World, College Dictionary. Four Edition (Foster City: IDG Books Worldwide, Inc, 2000), 1651

${ }^{5}$ Lorens Bagus, Kamus Filsafat (Jakarta: PT. Gramedia Pustaka Umum, 1996), 1090

${ }^{6}$ Semua ilmu psikologi yang murni lahir dari pengamatan dan pengujian (riset empiris) atas tingkah laku manusia yang memang dapat diamati; (Yakub Susabda, Menjadi Konselor Yang Profesional (Yogyakarta: Yayasan ANDI, 2007), 10

${ }^{7}$ Ronald E. Smith, Irwin G. Sarason, Psychology The frontier Of Behavior (New York: Harper \& Row Publisher, 1986), 4

${ }^{8}$ Carter \& Narramore, The Integration..., 11 
integrasi ini dengan anggapan bahwa keberadaan psikologi akan mengancam Gereja dan otoritas Firman Tuhan. MacArthur dan Mack mengutip pernyataan Bobgan yang menyatakan bahwa psikologi tidak lagi berbicara tentang mempelajari jiwa manusia; melainkan merupakan sekumpulan terapi dan teori yang berlainan, yang pada dasarnya bersifat manusiawi. Semua persangkaan dan sebagian besar doktrin psikologi tidak berhasil disatukan dengan kebenaran Kristen. ${ }^{9}$

Jadi, menurut MacArthur dan Mack, masuknya psikologi ke dalam ajaran Gereja telah mengaburkan garis yang membatasi pengubahan tingkah laku dengan pengudusan. Dengan tegas ditulis dalam buku Pengantar Konseling Alkitabiah bahwa "jalan menuju keutuhan adalah jalan pengudusan spiritual. Apakah kita akan berlaku dungu dengan berpaling dari Tuhan sebagai sumber air kehidupan itu, dan beralih pada hikmat dunia yang sensual dengan menggenangnya air behaviorisme?" ${ }^{10} \mathrm{Di}$ dalam artikel yang berjudul The Bible and Psychology-Oil and Water That Don't Mix yang ditulis oleh G. Harry Leafe, psikologi dianggap sebagai suatu system berpikir yang jika diintegrasikan dengan Firman Allah merupakan penghinaan. ${ }^{11}$ Jay E. Adams adalah seorang konselor yang dengan sangat berapi-api menentang integrasi. Dengan sangat serius, Adams mempertanyakan legitimasi terhadap psikiatris, ${ }^{12}$ yang merampas pekerjaan para pengkhotbah dan dalam kesibukannya mencoba untuk mengubah sikap dan nilai manusia ke dalam cara atau tingkah laku yang tidak baik. ${ }^{13}$ Menurut Adams, seperti yang dikutip oleh Gary A. Collins, "dengan mempelajari firman Allah dengan hati-hati dan mengamati bagaimana prinsip-prinsip Alkitab menggambarkan orang yang Anda nasihat ... Anda dapat memperoleh semua informasi dan pengalaman yang Anda butuhkan untuk menjadi kompeten, percaya diri konselor Kristen tanpa studi psikologi." 14 Jadi, dalam hal ini Adams tidak menyetujui theologia dan psikologi diintegrasikan dalam pelayanan pastoral konseling Kristen. Adams berpendapat bahwa hanya dengan prinsip-prinsip Alkitab

\footnotetext{
9 John F. MacArthur, Jr., Wayne A. Meck, Pengantar Konseling Alkitabiah (Malang: Gandum Mas, 2002), 27

${ }^{10}$ Ibid.

${ }^{11}$ Are we to suggest that such system of thought shoul be integrated" with the Word of God? The very thought of such an idea is blasphemeous!" G. Harry Leafe, The Bible and Psychology-Oil and Water That Don't Mix Internet (diakses 25 Sepetember 2007), 1

12 Bnd. Gary Garner, The Christian Faith and its Relevance to Counseling, Internet (diakses, 3 Agustus 2007 ), 11

${ }^{13}$ Bnd. Collins, Christian Counseling..., 18

${ }^{14}$ Ibid.
} 
juga kepercayaan diri konselor saja sudah cukup memadai dalam mengkonseling dan tidak perlu studi psikologi.

\section{KEBERDOSAAN MANUSIA}

Gambar Allah dalam diri manusia telah diselewengkan setelah kejatuhan. Gambar Allah mengalami malfungsi, tetapi tetap ada. Hilangnya gambar Allah dalam pengertian fungsional mempresaposisikan bertahannya gambar Allah dalam pengertian struktural. ${ }^{15}$ Kejatuhan manusia dalam dosa tidak menghancurkan kemanusiaan seseorang, meskipun kemampuan manusia untuk merefleksikan kekudusan Allah telah hilang tetapi manusia tetaplah manusia. H. Bavinck dan E. Brunner menyatakan bahwa, dosa meniadakan gambar Allah dalam arti yang lebih sempit atau material, manusia masih memiliki gambar Allah dalam arti yang lebih luas atau yang formal, yaitu bahwa manusia masih memiliki akal, kehendak, atau masih memiliki humanitas/peri kemanusiaan. ${ }^{16}$ Dosa adalah faktor penghalang yang besar. Menurut Plaisier, "Dosa menempatkan diri manusia di antara 'ada' dan 'menjadi.' Dosa ialah: manusia mau 'menjadi' apa yang ia tidak 'ada." "17 Jadi, sebagai orang yang telah berdosa, manusia menjadi makhluk yang tidak sesuai dengan keasliannya yaitu sebagai gambar Allah yang sempurna. Manusia yang telah jatuh dalam dosa tetap menyandang gambar Allah, dan karenanya harus dipahami bahwa gambar Allah merupakan aspek yang tak mungkin hilang dari manusia, bagian esensi dan eksisitensinya tidak hilang, namun gambar Allah harus dipahami sebagai keserupaan dengan Allah yang telah diselewengkan ketika manusia jatuh ke

\footnotetext{
${ }^{15}$ Gambar Allah meliputi struktur maupun fungsi karena gambar Allah mencakup keseluruhan pribadi. Manusia tidak bisa berfungsi tanpa adanya struktur tertentu. Seekor elang, misalnya, melintasi udara dengan cara terbang ini adalah salah satu fungsinya. Akan tetapi, elang takkan bisa terbang jika tidak memiliki sayap-salah satu strukturnya. Manusia juga diciptakan untuk melakukan fungsi-fungsi tertentu: menyembah Alah, mengasihi sesama, berkuasa atas alam, dan seterusnya. Tetapi semua fungsi itu takkan bisa kita lakukan jika Allah tidak mengaruniakan kapasitas-kapasitas struktural tertentu yang memampukan manusia untuk itu. Jadi, ketika memikirkan manusia sebagai gambar Allah, struktur dan fungsi sama-sama terlibat. Para theolog awal berkata bahwa gambar Allah di dalam diri manusia terutama terletak di dalam kapasitas strukturalnya (manusia memiliki rasio, moralitas, dan sebagainya); bnd. Anthony A. Hoekema, Manusia: Ciptaan Menurut Gambar Allah (Surabaya: Momentum, 2003), 88-89

${ }^{16}$ Bd. Harun Hadiwijono, Iman Kristen (Jakarta: BPK. Gunung Mulia, 2005), 204

${ }^{17}$ Arie Jan Plaisier, Manusia Gambar Allah: Terobosan-terobosan dalam Bidang Antropologi Kristen (Jakarta: BPK. Gunung Mulia, 2002), 79
} 
dalam dosa. Pengampunan dosa yang telah dilakukan oleh Yesus Kristus memungkinkan terjadinya rekonsiliasi antara manusia dengan Allah. Ketika Kitab Suci menyatakan bahwa kebenaran melalui iman, pandangan manusia dialihkan dari perbuatannya sendiri supaya manusia bersandar semata-mata pada kemurahan Allah (Rm 3:23-24). Dosa menyebabkan manusia terpisah dari Allah, dan akan tetap menjadi musuh Allah sampai ia dipulihkan di dalam anugerah melalui kebenaran Kristus (1Tim 1:15). Orang tersebut diterima ke dalam persekutuan dengan-Nya (1Kor 1:9), dibenarkan olehNya (Rm 5:1), yang terus-menerus dipulihkan dan diperbaharui dalam proses pengudusan (Kol 3:10).

\section{PANDANGAN PARA AHLI INTEGRASI TEOLOGI DAN PSIKOLOGI}

Manusia sebagai gambar Allah yang telah jatuh ke dalam dosa mengalami banyak perubahan dari berbagai segi, yang tentunya memiliki keterpecahan baik di dalam dimensi psikis maupun spiritualnya. ${ }^{18} \mathrm{Hal}$ inilah yang memungkinkan pengintegrasian antara teologi dan psikologi dalam menangani masalah psikhis dan rohani konseli. Karena dengan mengintegrasikan teologi dan psikologi, konseli dapat ditolong untuk memperbaiki pengertian akan keberadaan dirinya dan penerimaan diri. Psikologi melakukan observasi berupa penelitian atau pertanyaan dan memberikan data yang berkaitan dengan pemahaman teologis tentang manusia, dan teologi mengungkapkan kebenaran ilahi mengenai psikologi perkembangan manusia. ${ }^{19}$ Integrasi adalah proses dimana dua atau lebih disiplin ilmu dengan tetap mempertahankan identitas mereka sendiri sekaligus memetik manfaat dari sudut pandang masing-masing dan mengkomunikasikan kebenaran yang sama. ${ }^{20}$ Jadi, integrasi teologi dan psikologi perlu dan dapat digunakan, dimana kedua disiplin ilmu tersebut dapat mempertahankan identitasnya sambil menarik manfaat dari perspektif masing-masing dalam mengkomunikasikannya demi memperoleh dan memberikan suatu pandangan atau pengertian yang baru dan komprehensif.

\footnotetext{
${ }^{18}$ Shinichi Tamagi, Fragmentation And Integration: A Thought On Bases For Artistic Expression; Artikel, 190-191

19 John D. Carter dan Bruce Narramore, The Integration Of Psychology and Theology (Grand Rapids, Michigan: Zondervan, 1980), 20

${ }^{20}$ Kirk E. Farnsworth, Whole Hearted Integration (Grand Rapids, Michigan: Baker Book House, 1985), 11
} 
Integrasi antara teologi dan psikologi dalam pelayanan konseling Kristen adalah sangat baik yakni untuk menolong pribadi yang mengalami masalah (konseli) guna menghadapi masalah yang dihadapi. Firman Allah memiliki relevansi besar dan abadi untuk konselor atau konselinya, tetapi tidak mengklaim untuk menjadi dan juga bukan dimaksudkan untuk menjadi wahyu Allah satu-satunya dalam menolong manusia. Dalam dunia kedokteran, juga menolong umat manusia, manusia telah diizinkan untuk belajar banyak tentang ciptaan Allah melalui ilmu pengetahuan dan studi akademis. Mengapa, kemudian, psikologi ketika akan dipilih sebagai salah satu bidang yang memiliki kontribusi pada pekerjaan konselor atau dunia konseling ditolak ${ }^{21}$ Berkenaan dengan ini, dikemukakan oleh Susabda: "Memang kita tidak perlu terlalu naïf dan percaya bahwa setiap masalah hidup manusia adalah masalah dosa (spiritual), tetapi kita harus mengakui bahwa kebutuhan manusia yang terdalam selalu bersangkut paut dengan penyelesaian masalah dosa (spiritual)." ${ }^{22}$ Hal ini mendukung pernyataan John H. Stoll dalam artikelnya mengenai The Bible and Psychology, bahwa "psikologi dapat menyediakan alat-alat yang disediakan oleh Tuhan untuk menembus lebih efisien, dan melarutkan pertahanan yang digunakan orang untuk mengisolasi diri dari kebenaran Alkitab, dan dari sesama mereka. ${ }^{23}$ Untuk mengetahui dan memahami masalah dosa konseli, seorang konselor perlu memahami permasalahan secara psikis yang dialami oleh konseli. Hal ini merupakan suatu keistimewaan bagi konselor-konselor Kristen. Pendekatan Pastoral Konseling mempunyai skop yang jauh lebih luas jikalau dibandingkan dengan skop pelayanan konseling dari konselorkonselor lainnya, bukan karena availabilitas dan keunikan posisi hamba Tuhan di tengah jemaatnya saja tetapi juga disebabkan oleh karena nature dari pelayanan Pastoral Konseling yang menempatkan dimensi spiritual sebagai inti dasar pendekatan setiap masalah hidup manusia.

\section{PERBEDAAN MENDASAR ANTARA TEOLOGI DAN PSIKOLOGI}

${ }^{21}$ Gary R. Collins, Christian counseling A Comprehensive Guide (Waco: Word Books, 1982), 19

${ }^{22}$ Yakub B. Susabda, Pastoral Konseling. Jilid 2 (Malang: Gandum Mas, 1986), 5

${ }^{23}$ John H. Stoll, The Bible and Psychology, http:// leaderu. Com/ offices/ stoll/ psychology.html: (diakses, 25 September 2007), no.pp. 
Untuk lebih memudahkan memahami perbedaan yang mendasar antara teologi dan psikologi dapat dilihat dalam beberapa aspek: ${ }^{24}$

\section{Berpusat Pada Allah}

Fokus teologi Kristen adalah berpusat pada Allah (God-centered), sedangkan psikologi berpusat pada manusia (man-centered). Alkitab mengajarkan tentang tujuan hidup manusia adalah untuk memuliakan Allah. Oleh karena itu, segala sesuatunya harus ditaklukkan oleh seseorang untuk mencapai tujuan tersebut. Psikologi yang didasarkan pada mancentered, mempunyai tujuan untuk mencapai kebahagiaan individual.

\section{Natur Manusia}

Teologi Kristen mengajarkan bahwa natur manusia adalah berdosa. Alkitab menyatakan bahwa, "karena semua orang telah berbuat dosa dan telah kehilangan kemuliaan Allah" (Rm 3:23). Lebih lanjut ditegaskan oleh Sproul bahwa, "Sebenarnya umat manusia waktu hadir di dalam dunia ini sudah dalam keadaan berdosa. Semua manusia dilihat sebagai orang berdosa oleh Allah." 25 Sedangkan psikologi mengajarkan bahwa natur manusia pada dasarnya adalah baik, atau setidaknya netral. Alasan sesungguhnya manusia bertingkah laku salah adalah karena tekanan dari luar dirinya. ${ }^{26}$ Kebanyakan pemikiran psikologis percaya bahwa pada dasarnya manusia itu baik dan melalui upayanya sendiri diri manusia dapat meningkatkan kehidupan tanpa Allah. Psikologi juga mengajarkan bahwa manusia adalah korban dari masa lalunya dan masalah itu berasal dari orang-orang dan lingkungan yang negatif mempengaruhi manusia di masa lalu. ${ }^{27}$ Dengan kata lain psikologi tidak mengakui natur manusia sebagai

${ }^{24}$ Steven J. Cole, How John Calvin Led Me to Repent of Christian Psychology, http://www.freerepublic.com, (diakses, 30 Januari 2008)

25 R.C. Sproul, Kebenaran-kebenaran Dasar Iman Kristen (Malang: SAAT, 1997), 194

${ }^{26}$ Psychology theaches that human nature is basically good, or at least neutral. The only reason that people misbehave is because of outside forces (such as society or parents) that harm them. www.svchapel. Org/ assets/ docs/ theologylessons/ christian and psychology.pdf, (diakses, 18 Januari 2008)

${ }^{27}$ Debbie O’Hara, Christianity Versus Psychology, http://newswithviews/ Ohara/ debbie16.htm, (diakses, 29 Januari 2008) 
orang berdosa tetapi setiap masalah yang dialami oleh seseorang pada masa sekarang ini adalah akibat dari kesalahan yang dialaminya pada masa lalu.

\section{Nilai}

Mengenai nilai, Alkitab mengajarkan mengenai ke-absolut-an. Sutjipto Subeno menyatakan, kebenaran sejati bersumber dari Allah sendiri. Manusia bukanlah sumber kebenaran, karena manusia sendiri masih mencari kebenaran, dan manusia sendiri sadar bahwa tingkat pengetahuan kebenarannya tidaklah absolut. ${ }^{28}$ Sedangkan psikologi mengajarkan tentang relatif. ${ }^{29}$ Sesuatu yang dipandang baik oleh seseorang, belum tentu dilihat baik juga oleh orang lain. Dalam mencari kebenaran, haruslah kembali kepada Allah sendiri, yang menjadi sumber kebenaran dan diri-Nya sendiri adalah kebenaran (Yoh 14:6).

\section{Sumber Jawaban}

Sumber jawaban dalam ilmu psikologi adalah di dalam diri individu itu sendiri. Tugas dari seorang konselor hanyalah menolong konseli untuk menemukan jawabannya. Sedangkan orang Kristen percaya bahwa jawaban-jawaban dalam hidup ini terdapat di dalam Fiman Tuhan yang telah dinyatakan oleh Allah. Berkaitan dengan ini, Subeno menulis, Allah mewahyukan kebenaran di dalam Alkitab. Allah menyatakan kebenaranNya kepada manusia melalui firman-Nya, yaitu Alkitab. Inilah yang ditekankan dengan proklamasi: Sola Scriptura (Hanya Alkitab Saja). ${ }^{30}$ Dengan demikian, maka seluruh kebenaran harus didasarkan pada Alkitab.

\section{Metode}

Sebagaimana pengertian psikologi mengenai natur manusia di atas, maka psikologi mengajarkan bahwa kunci dari masalah pribadi yang dialami oleh tiap individu terdapat pada masa lampau (past). ${ }^{31}$ Dibandingkan dengan apa yang dinyatakan di dalam Alkitab, Alkitab selalu memperhadapkan manusia dengan apa yang terjadi pada masa lampau,

${ }^{28}$ Sutjipto Subeno, Presuposisi Teologi: Sistematika, Edisi: 035/I/2003.

${ }^{29}$ Steven J. Cole, How John Calvin Led Me to Repent of Christian Psychology, http://www.freerepublic.com

${ }^{30}$ Subeno, Ibid.

${ }^{31} \mathrm{Bd}$. www.svchapel.org/assets/docs/theologylessons/ (diakses, 29 Januari 2008) 
yaitu manusia berdosa, masa sekarang ini, sebagai manusia yang telah diselamatkan dan juga memperhadapkan manusia pada masa yang akan datang, yakni kehidupan kekal bersama Kristus di Surga.

\section{ILMU PENGETAHUAN SEBAGAI PENYATAAN UMUM ALLAH}

Kedaulatan Allah yang mutlak dan wahyu-Nya yang penuh hikmat bukan saja menetapkan, tapi juga memberikan inspirasi dan menggerakkan manusia untuk menyembah-Nya. Dengan inisiatif-Nya sendiri, Allah memberikan inspirasi yang berdasarkan kedaulatan-Nya untuk menyatakan hikmat Allah kepada manusia. Wahyu umum diberikan kepada manusia dan manusia memberikan respon karena manusia adalah satu-satunya makhluk yang dapat memberi respon kepada Allah. Menurut Stephen Tong, respon terhadap wahyu umum Allah membuat manusia menemukan tiga jenis kewajiban yang harus dipenuhi yaitu transcending nature, mengatur diri sendiri, dan beribadah kepada Allah. ${ }^{32}$ Penyataan umum memiliki pengertian penyataan diri Allah (self-disclosure) melalui ciptaan-Nya kepada umat manusia di muka bumi ini sepanjang waktu dan sejarah dengan penuh kuasa dan hikmat ilahi. ${ }^{33}$ Hal ini juga nyata di dalam nyanyian Daud di dalam Mazmur 19:2, "Langit menceritakan kemuliaan Allah dan cakrawala memberitakan pekerjaan tangan-Nya." Manusia dalam segala keterbatasannya tidak akan dapat menghampiri bahkan mengenal Allah pencipta yang kudus, untuk itu Allah sendiri yang berinisiatif untuk menyatakan diri-Nya kepada manusia. Satu-satunya cara untuk mengenalNya adalah melalui wahyu. Tidak ada manusia yang bisa melihat-Nya kecuali DIA sendiri menyingkapkan dan menyatakan diri-Nya kepada kita.

\footnotetext{
${ }^{32}$ Respon terhadap wahyu umum Allah membuat manusia menemukan tiga jenis kewajiban yang harus dia penuhi.1) Kewajiban karena keberadaanku, keberadaan trancending nature, yaitu keberadaan untuk menopang alam. Jadi bukan hanya sekedar mengontrol alam dan mengatur alam saja, tapi juga memperbaiki alam...2) Respon terhadap wahyu umum Allah adalah bagaimana mengurus diri kita sendiri. Bagaimana kita mampu melimitasi dirisehingga kita bisa menjadi manusia yang bertanggung jawab, baik terhadap alam, diri sendiri, orang lain dan Allah. Mengatur diri sendiri berada di atas hal mengatur alam. 3) Karena kuasa mengatur alam dan diri sendiri inilah maka timbullah respon beribadah dan takut kepada Allah; Stephen Tong, Dosa dan Kebudayaan (Jakarta: LRII, 1997), 20

${ }^{33}$ Karena apa yang dapat mereka ketahui tentang Allah nyata bagi mereka, sebab Allah telah menyatakannya kepada mereka. Sebab apa yang tidak nampak dari padaNya,yaitu kekuatan-Nya yang kekal dan keilahian-Nya, dapat nampak kepada pikiran dari karya-Nya sejak dunia diciptakan, sehingga mereka tidak dapat berdalih ( $R m$ 1:19-20).
} 
Pengertian mengenai penyataan umum diartikan oleh Bruce Demarest and Gordon Lewis, "Wahyu Umum, dimediasi melalui alam, hati nurani, dan sejarah, secara tradisional telah dipahami sebagai saksi universal untuk keberadaan Allah dan karakter-Nya"34 Selanjutnya dinyatakan bahwa, Pengungkapan Allah nyata di alam semesta, dalam sejarah, dan hukum moral di dalam hati, dimana semua orang sepanjang waktu dan tempat mendapatkan pemahaman dasar mengenai Pencipta dan tuntutan moralnya. ${ }^{35}$ Dengan demikian, selain melalui perbuatan Allah dalam alam semesta dan sejarah, Allah menyatakan diri pula kepada manusia melalui hati nurani atau suara hati manusia seperti yang dinyatakan oleh rasul Paulus di dalam Roma 2:14-15. ${ }^{36}$

\section{INTEGRASI TEOLOGI DAN PSIKOLOGI}

Setelah menguraikan mengenai ilmu pengetahuan umum sebagai penyataan umum Allah kepada manusia, maka di bawah ini penulis akan memaparkan mengenai integrasi antara teologi dan psikologi.

\section{Perbandingan Teologi dan Psikologi yang Potensial}

Menurut Meier dan Minirth, antipati orang-orang Kristen terhadap psikologi merupakan hasil kesukaran dalam mendefinisikan secara tepat di mana psikologi secara disiplin ilmu dimulai dan di mana harus berakhir. ${ }^{37}$ Namun, melalui tabel di bawah ini dapat dilihat perbandingan yang potensial dan dapat dipakai sebagai pendekatan di antara kedua ilmu ini.

\section{Wilayah Perbandingan Yang Potensial dan Kompatibilitas}

34 B.A. Demarest, General Revelation: Historical Views and Contemporary Issues, (Grand Rapids, Michigan: Zondervan, 1982), 14

35 B.A. Demarest and G.R.Lewis, Integrative Theology: Knowing Ultimate Reality, the Living God. Vol. 3 (Grand Rapids, Michigan: Zondervan, 1987), 61

${ }^{36}$ Apabila bangsa-bangsa yang tidak memiliki hukum Taurat oleh dorongan diri sendiri melakukan apa yang dituntut hukum Taurat, maka, walaupun mereka tidak memiliki hukum Taurat, mereka menjadi hukum Taurat bagi diri mereka sendiri. Sebab dengan itu mereka menunjukkan, bahwa isi hukum Taurat ada tertulis di dalam hati mereka dan suara hati mereka turut bersaksi dan pikiran mereka saling menuduh atau saling membela (Rm 2:14-15), ...., Alkitab (Jakarta: Lembaga Alkitab Indonesia, 2006)

${ }^{37}$ Paul D. Meier, Frank B. Minirth, Pengantar Psikologi dan Konseling Kristen (Yogyakarta: ANDI, 2004), 18 
Missio Ecclesiae, 3 (2), Oktober 2014, 128-144

\begin{tabular}{|l|l|l|}
\hline \multicolumn{1}{|c|}{ Teologi } & \multicolumn{1}{|c|}{ Psikologi } & \multicolumn{1}{c|}{ Contoh } \\
\hline Dosa & Psikologi Abnormal & Peck 1983 \\
\hline $\begin{array}{l}\text { Keselamatan dan Pertumbuhan } \\
\text { Rohani }\end{array}$ & Psikologi Perkembangan & Darling 1969; Benner 1988 \\
\hline Gereja & Psikologi Sosial & Bolt and Myers 1984; Griffin 1982 \\
\hline Malaikat & Parapsikologi & Koteskey 1980 \\
\hline Kristus dan Roh Kudus & Psikologi Konseling & McKenna 1977; Gilbert \& Brock 1985 \\
\hline Karakter Manusia & Personaliti & Burke 1967 \\
\hline Hal-hal yang Muncul & Psikologi Perilaku & Bufford 1981 \\
\hline
\end{tabular}

Sumber: Diadaptasi dari Carter dan Mohline 1976; Collins 1981; Meier dan Minirth 2004

Cakupan ilmu teologi dan psikologi yang luas membuat sulit untuk memfokuskan diri pada satu titik temu tetapi melalui tabel tersebut di atas dapat dilihat bahwa baik teologi maupun psikologi dapat diintegrasikan demi mengembangkan pelayanan konseling Kristen.

\section{Cara Penerapan Integrasi}

Carter dan Narramore menyarankan empat cara penerapan integrasi ${ }^{38}$ untuk menghubungkan teologi Kristen dan psikologi. Adapun keempat model integrasi tersebut adalah sebagai berikut.

\section{The Against Model}

Model ini merupakan posisi kekristenan melawan posisi psikologi ${ }^{39}$ dan dibangun berdasarkan asumsi bahwa ada konflik yang tak dapat diselesaikan antara psikologi dan kekristenan. ${ }^{40}$ Yang berpihak pada posisi

38 John D. Carter and Bruce Narramore, The Integration Of Psychology and Theology (Grand Rapids, Michigan: Zondervan, 1978),73

${ }^{39}$ Meier dan Minirth, Pengantar Psikologi..., 12-13

${ }^{40}$ Carter and Narramore, The Integration Of..., 73 
kekristenan melawan psikologi tidak melihat nilai psikologi sehingga mengurangi semua masalah hanya dalam arena rohani. ${ }^{41}$ Mendukung hal ini, Benner menyatakan bahwa, pengurangan nilai rohani semacam ini membuat psikoterapi bertentangan dengan tujuan Allah. ${ }^{42}$

\section{The Of Model}

Pada bagian ini psikologi dianggap memiliki jawaban-jawaban sementara kekristenan dipandang sebagai sesuatu yang tidak penting atau bahkan merusak kehidupan yang sehat. ${ }^{43}$ Freud menekankan bahwa kekristenan bersifat patologis (penyakit). ${ }^{44}$ Menurut Minirth dan Meier, baik The Against Model maupun The Of Model sama-sama terlalu menyerdehanakan masalah dengan mengurangi segala sesuatu pada satu sudut pandang. ${ }^{45}$

\section{The Parallels Model}

Pada model ini, baik teologi maupun psikologi adalah dua ilmu yang terpisah namun sejajar untuk menemukan kebenaran. ${ }^{46}$ Menurut Benner, sifat dualistik pemisahan ini berlawanan dengan Alkitab. ${ }^{47}$

\section{The Integration Model}

Model pendekatan terakhir ini adalah psikologi berintegrasi dengan kekristenan. Menurut Carter dan Narramore, model integrasi ini berakar pada asumsi bahwa Allah adalah pencipta seluruh kebenaran. ${ }^{48}$

Setiap model yang di atas, memiliki kekuatan dan kelemahannya masing-masing. Model integrasi dari Carter dan Narramore, baik Against dan $O f$ tidak memiliki keuntungan apa pun karena masing-masing bertahan

\footnotetext{
Baker, 1988), 44

${ }^{43}$ Meier dan Minirth, Ibid., 13

${ }^{44}$ Benner, Psychotherapy..., 47- 48

${ }^{45}$ Meier dan Minirth, Ibid., 13

${ }^{46}$ Carter and Narramore, The Integration Of ..., 94

${ }^{47}$ Benner, Ibid., 41

${ }^{48}$ Integration model is rooted in the assumption that God is the author of all truth; Carter and Narramore, Ibid., 103
}

${ }^{41}$ Meier dan Minirth, Ibid., 12-13

42 D. Benner, Psychotherapy and the Spiritual Quest (Grand Rapids, Michigan: 
dengan prinsipnya, dan model parallels mempunyai beberapa kekuatan dasar tapi terbatas karena keduanya bergerak pada rel masing-masing tanpa bersinggungan. Hanya model integration yang cukup lengkap karena kedua ilmu yang pada dasarnya bertolak belakang ini dapat diintegrasikan, asalkan tidak bertentangan atau sesuai dengan prinsip Alkitab karena iman Kristen bukan iman yang self-centered atau human-centered tetapi iman yang dibangun di atas dasar Alkitab dan Kristus atau Christ-centered.

\section{Cara Mengintegrasikan Iman Kristen dan Ilmu Pengetahuan}

Sesudah menguraikan mengenai cara penerapan integrasi, maka penulis akan memaparkan enam cara pendekatan integrasi teologi dan psikologi sesuai dengan pendapat para ahli konselor Kristen. ${ }^{49}$

\section{Expanded Empiricism}

Mengakui bahwa semua kebenaran adalah kebenaran Allah. Kebenaran dalam dunia psikologi adalah kebenaran Allah, asalkan tidak bertentangan dengan kebenaran Allah yang tertera di dalam Alkitab. Alkitab adalah kebenaran yang menyelamatkan, sedangkan kebenaran yang ditemukan di dalam dan melalui ilmu pengetahuan adalah kebenarankebenaran yang melengkapi kebutuhan orang percaya yang kontekstual. ${ }^{50}$

\section{Diterminism and Free Will}

Alkitab tidak menyembunyikam fakta mengajarkan dengan sangat jelas bahwa di satu pihak Allah adalah Allah dan yang berdaulat, mahatahu, dan berencana yang menentukan segala sesuatu, namun di pihak lain, Ia juga memberikan kebebasan kepada manusia yang terikat pada diri-Nya. ${ }^{51}$

\section{Biblical Absolutism}

Alkitab menyediakan dasar/prinsip-pinsip semua kasus. ${ }^{52}$ Memang Alkitab bukanlah buku ilmu pengetahuan, karenanya ada fakta di mana

\footnotetext{
${ }^{49}$ Bnd. Yakub Susabda, Pastoral Konseling. I (Malang: Gandum Mas, 2006), 94

${ }^{50}$ Bnd. Ibid.

${ }^{51}$ Ibid., 95

${ }^{52}$ Stevri Lumintang, Integrasi Theologia dan Psikologi, Bahan Seminar.
} 
dalam hal-hal tertentu Alkitab "diam." Misalnya pemakaian shock therapy atau electro convulsive therapy, yang diberikan pada pasien schzophrenia, ${ }^{53}$ Alkitab seolah-olah tidak berbicara apa-apa, namun semua ini tidak lepas dari dasar, tujuan dan motivasi tekhnik terapi.

\section{Modified Reductionism}

Bagian ini dijelaskan oleh Gary Collins sebagi suatu usaha dari para ahli kimia, dokter, bahkan psikolog yang cenderung untuk melakukan pemotongan-pemotongan, mendekati persoalan di sekitar manusia terlepas dari keutuhannya sebagai ciptaan Allah yang teristimewa (Mzm 8:5-6).

\section{Christian Supernaturalism}

Allah adalah Allah yang berintervensi dalam kehidupan manusia, dan memelihara manusia sampai pada hal-hal yang detail. Oleh karena itu, sumbangan psikologi adalah sumbangan yang tidak merusak keyakinan manusia orang percaya mengenai intervensi dan pemeliharaan Tuhan.

\section{Biblical Anthropology}

Manusia adalah makhluk ciptaan Allah yang teristimewa karena diciptakan menurut gambar dan rupa Allah. Namun manusia kemudian jatuh dalam dosa, sehingga hidupnya rusak total di hadapan Allah. Manusia tidak mampu berkomunikasi lagi dengan pencipta-Nya. Allah menyediakan pengharapan kepada manusia melalui pengalaman kelahiran kembali dan percaya kepada Tuhan Yesus Kristus. Jadi, ilmu psikologi yang disumbangkan dapat diterima apabila sumbangan tersebut tidak merusak prinsip-prinsip Alkitab.

Untuk mencermati ilmu pengetahuan sebagai penyataan umum Allah, Larry Crabb menggambarkan di dalam sebuah diagram seperti berikut.

${ }^{53}$ Susabda, Ibid., 95-6 


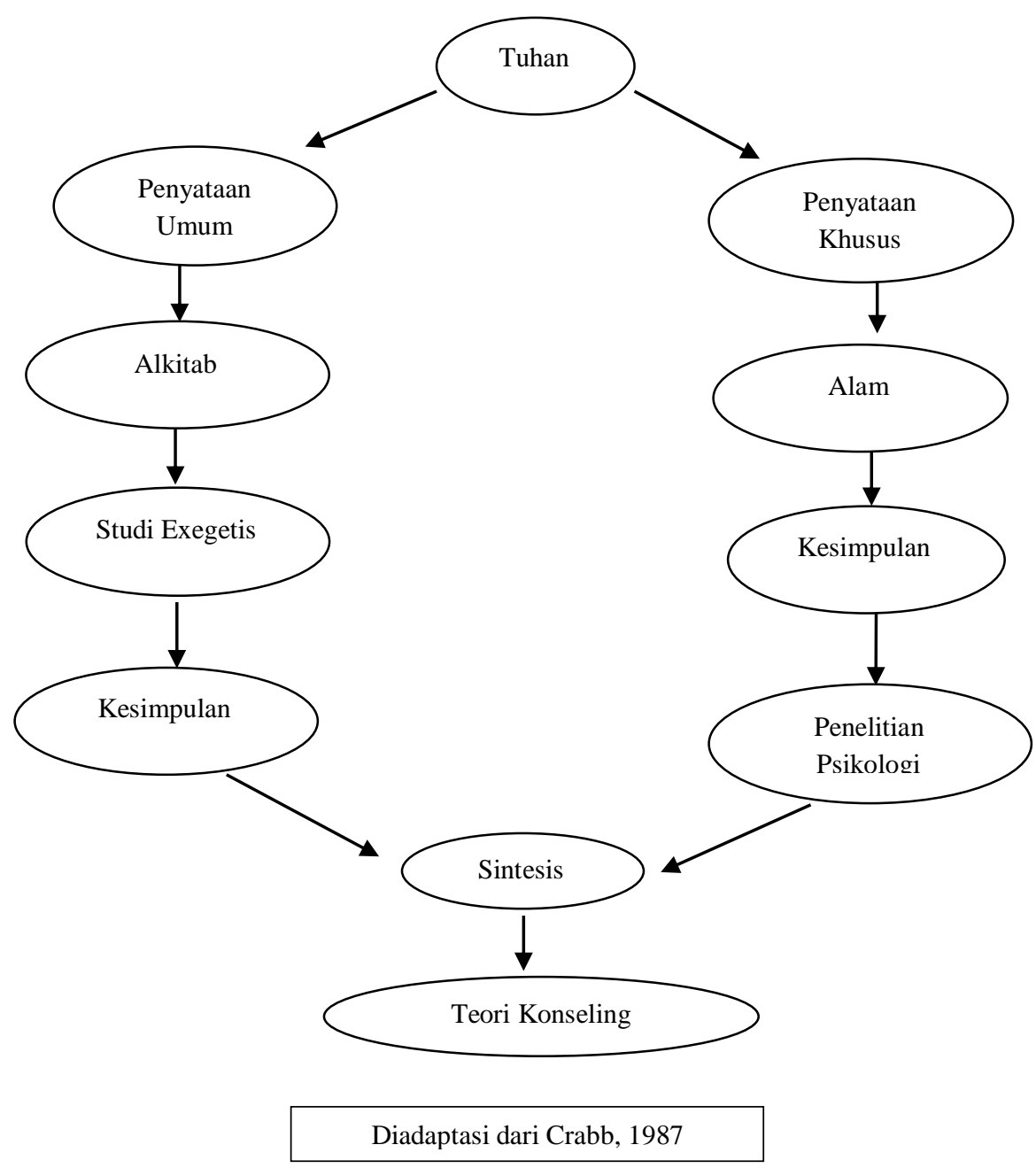

Melalui diagram di atas, ${ }^{54}$ terlihat jelas bahwa sumber utama pengetahuan adalah Tuhan saat Dia menyatakan penyataan-Nya. Dasar utama untuk memahami psikologi adalah Tuhan sendiri dan apapun yang menjadi kesimpulan akhir sebuah penelitian, baik itu studi teologis maupun psikologis harus konsisten dengan Alkitab sebagai dasar pijakan baik penyataan umum maupun penyataan khusus. Masing-masing sumber ini memiliki suatu metode data analisis tertentu. Teologi, hermeneutika dipakai untuk mempelajari Alkitab, sementara metode ilmiah dipakai untuk mempelajarai alam dan manusia. Kesimpulan yang dicapai oleh kedua 1987), 38

${ }^{54}$ Larry Crabb, Understanding People (Michigan, Grand Rapids: Zondervan, 
sumber ini berbeda karena perbedaan sumber dan metode analisis, namun pada tingkat analisis akhir akan ditemukan kesamaan, saling mengisi dan interaktif. ${ }^{55}$

Jadi, akan terjadi dan terdapat refleksi teologis dan alkitabiah atas psikologi dan refleksi psikologis atas theologia dan Alkitab. Konflikkonflik yang terjadi antara theologia dan psikologi merupakan kesalahan tafsiran alkitabiah atau kesalahan dalam penggunaan metode ilmiah, atau keduanya. Teologi maupun psikologi diturunkan dari pewahyuan Allah, penemuan-penemuan yang akurat dari masing-masing metode tidak akan berkonflik." 56

Psikologi adalah bagian dari hidup dengan Allah, suatu pengesahan bahwa Allah beserta orang percaya, dan adalah izin yang diberikan oleh Tuhan, dan realitas tergantung pada Allah saja." ${ }^{27}$ Ilmu pengetahuan psikologi tidak bisa disingkirkan begitu saja hanya karena tidak secara spesifik tertera di dalam Alkitab, karena psikologi dapat dipergunakan untuk pelayanan pekerjaan Tuhan asalkan ilmu pengetahuan ini diletakkan seutuhnya di bawah otoritas Firman Allah. Psikologi adalah ilmu pengetahuan yang juga mengandung kebenaran-kebenaran tertentu di dalamnya. Lebih lanjut dinyatakan oleh Simanjuntak bahwa kebenarankebenaran melalui ilmu pengetahuan ini disebut sebagai God's law sedangkan kesimpulan-kesimpulan dari dari kebenaran ilmu pengetahuan itu disebut God's truth jikalau hal itu harmonis dengan God's law lainnya. ${ }^{58}$ Jadi jika kesimpulan-kesimpulan dari psikologi mengandung kebenaran Allah, maka dapat dan harus digunakan dalam konseling Kristen.

Menurut Buttrick, keutuhan itulah yang menjadi visi kedatangan, kehidupan dan pelayanan Yesus hingga memberikan nyawa-Nya, yakni agar domba-domba-Nya mengalami kelimpahan dalam segala aspek hidup. ${ }^{59}$ Hal inilah yang memungkinkan dibangunnya dasar integrasi antara teologi dan psikologi karena psikologi didasarkan pada penyataan umum Allah yang dinyatakan kepada manusia.

${ }^{55}$ Meier dan Minirth, Pengantar Psikologi..., 18

${ }^{56}$ Ibid.

${ }^{57}$ Kirk. E. Farnswoth, Psychology and Christianity: A Substantial Integration, JASA 27 (June 1975): 60-66

58 Julianto Simanjuntak, Konseling Gangguan Jiwa dan Okultisme (Jakarta: Gramedia, 2008), 125-126

59 George Arthur Buttrick (Ed). The Inerprester's Dictionary Of The Bible (Nashville: Abingdon Press, 1991), 546 


\section{PENUTUP}

Teologi dan psikologi merupakan dua ilmu yang sangat berbeda sehingga tindakan untuk mengintegrasikan teologi dan psikologi bukan masalah yang mudah. Meskipun memiliki tujuan yang terbaik untuk tetap alkitabiah, namun sangatlah tidak mudah untuk mengakui konsep-konsep psikologi atau pemikiran yang berkompromi dengan isi Alkitab. Akibat yang biasa dilakukan namun berbahaya adalah kecenderungan melihat kepada ajaran Alkitab melalui kacamata psikologi sementara kebutuhan kritis adalah melihat kepada psikologi melalui pandangan atau ajaran Alkitab. Teologi (dalam hal ini teologi Kristen) atau kekristenan dan psikologi dapat diintegrasikan, asalkan psikologi berada di bawah otoritas Alkitab. Dengan berotoritaskan Alkitab, maka apabila ajaran Alkitab mengalami konflik dengan konsep atau ajaran apapun, ajaran Alkitab akan tetap diterima sebagai kebenaran karena Alkitab adalah penyataan Allah yang tidak dapat salah. Sedangkan jika konsep lain, sekalipun didukung oleh penelitian ilmiah tetapi jika tidak sesuai dengan kebenaran Alkitab, maka tidak dapat diterima sebagai kebenaran. Dengan berlandaskan kepada Allah dan penyataan-Nya kepada manusia baik itu penyataan khusus maupun penyataan umum, integrasi teologi dan psikologi sesuai dengan perspektif Alkitab yaitu melayani dan memandang manusia ciptaan Allah sebagai satu keutuhan.

Dengan demikian konselor Kristen dapat menerima psikologi hanya jika aspek-aspeknya selaras dengan kebenaran Alkitab dan juga sebaliknya. Maka di dalam memformulasikan proses integrasi antara teologi dan psikologi harus diperhatikan bahwa, sangat tidak beralasan bagi orang Kristen untuk menolak semua hal tentang psikologi yang dibangun di atas dasar ilmu pengetahuan, sebaliknya tidak ada alasan untuk menolak kekristenan hanya karena berlandaskan pada Alkitab. Masalah dalam integrasi, khususnya dalam bidang theologia dan psikologi adalah bagaimana membawa kebenaran Allah, dari segala bidang yang diciptakanNya, untuk menunjang karya-Nya atas umat manusia secara utuh. 